\title{
Synthesis, Infrared and Mössbauer Characterization of Some Chloridestannate (IV) Inorganic-organic Hybrid Complexes: Sn-Ph Bonds Cleavage
}

\author{
Dame Seye*, Mouhamadou Birame Diop, Assane Toure, Tidiane Diop, Cheikh Abdoul Khadir Diop, \\ Mamadou Sidibe, Aminata Diasse Sarr, Libasse Diop
}

Mineral and Analyical Chemestry Laboratory, Deparement of Chemesry, Faculy of Science and Technology, Cheikh Anta Diop Universiy, Dakar, Senegal

\author{
Email address: \\ dsdjamil@gmail.com (D. Seye) \\ ${ }^{*}$ Corresponding author
}

To cite this article:

Dame Seye, Mouhamadou Birame Diop, Assane Toure, Tidiane Diop, Cheikh Abdoul Khadir Diop, Mamadou Sidibe, Aminata Diasse Sarr, Libasse Diop. Synthesis, Infrared and Mössbauer Characterization of Some Chloridestannate (IV) Inorganic-organic Hybrid Complexes: Sn-Ph Bonds Cleavage. American Journal of Heterocyclic Chemistry. Vol. 5, No.4, 2019, pp. 81-85. doi: 10.11648/j.ajhc.20190504.12

Received: February 13, 2020; Accepted: February 27, 2020; Published: March 10, 2020

\begin{abstract}
Five new compounds are isolated from reactions carried out in solution. All the compounds are characterized by, Infrared and Mössbauer spectroscopies. Spectroscopic studies have shown the presence of different carracterristic bands, notably $v(\mathrm{PO})$ vibrations coming from triphenylphosphine oxide, with wide absorption due to the $\mathrm{NH}_{2}$ groups coming from urea and the intense doublet which show the presence of phenyl groups. The proposed structures, in the solid state, are discrete though hydrogen bonding interactions may occur. Event in this study is the dearylation evidenced, cleaved $\mathrm{Sn}-\mathrm{Ph}$ bonds occurring in the presence of triphenylphosphine oxide or urea, during some reaction processes. In the presence of triphenylphosphine oxide, the dearylation is followed by the formation of $\mathrm{Sn}-\mathrm{Cl}$ new bonds while in the presence of urea, the $\mathrm{Sn}-\mathrm{Ph}$ bonds cleavage undergo with a deamination of the urea giving rise to the formation of $\mathrm{Sn}-\mathrm{N}$ and $\mathrm{Sn}-\mathrm{Cl}$ new bonds whose presence are ascertained by the Mössbauer parameters. The oxidation of tin (II) to tin (IV) as well as the coordination behavior of the oxonium, $\mathrm{H}_{3} \mathrm{O}^{+}$cation is also noted in this work. In the reaction of triphenylphosphine oxide with $\mathrm{SnCl}_{2} .2 \mathrm{H}_{2} \mathrm{O}$ and nitric acid, we have obtained compounds in which tin has oxidized. The reactions between urea and $\mathrm{SnPh}_{3} \mathrm{Cl}$ are the site of a species exchange which can be explained by a deamination of urea and a dephenylation of $\mathrm{SnPh}_{3} \mathrm{Cl}$ Studies aimed at understanding the processes of this transformation still unknown leading to the isolation of aminochlorotin (IV) compounds and isolating their single crystals are being carried in our laboratory (LA.CHI.MI.A).
\end{abstract}

Keywords: Chloride, Infrared, Mössbauer, Sn-Ph Bonds Cleavage, Tin (IV), Urea Deamination

\section{Introduction}

Organotin materials display interesting properties and have multiple applications. They exhibit, for example, inhibition towards pancreatic cancer cells [1-4], anticancer activity [5-7], catalysis application [8], fungicidal activity [9]. Moreover, they are used in the preparation of some thin-film transistors matrix [10]. In the seventies, several crystalline structures of tin (IV) compounds with ligand such as $\mathrm{Ph}_{3} \mathrm{AsO}, \mathrm{PyO}, \mathrm{Ph}_{3} \mathrm{PO}$ were reported [11-13]. In these complexes, the $\mathrm{OSnPh}_{3} \mathrm{O}$ cores are in a trans-trigonal bipyramidal arrangement whith the phenyl groups in equatorial positions. The Dakar group has been involved in the development of halo- and organotin (IV) class of compounds since more than two decades. We recently have described the spectroscopic characterization of the complex $\left[\left(\mathrm{PhCH}_{2}\right) \mathrm{Ph}_{3} \mathrm{P}\left(\mathrm{NO}_{3}\right)\right]\left[\left(\mathrm{SnPh}_{3} \mathrm{Cl}\right)_{3}\right]$ [14] which contains a central tridentate nitrate anion linked to tin centres. $\mathrm{Sn}-\mathrm{Ph}$ bonds exhibit a reasonable labile character and can be cleaved in some conditions. Numerous works especially those reporting crystalline structures evidencing the presence of $\mathrm{Sn}-\mathrm{Ph}$ bonds cleaved from partial to total dearylation $[15,16]$ have been published. In these studies, the dearylation generally occur when reactions happen in organic solvent solutions and, new bonds are trained because the tin atom 
affords multiple possible synthons. In this work, we investigated, in organic solvent, at room temperature, the interactions between dichloridotin (II) dihydrate, $\mathrm{SnCl}_{2} \cdot \mathrm{H}_{2} \mathrm{O}$ and, cetyltrimethylbromide, $\mathrm{C}_{19} \mathrm{H}_{42} \mathrm{NBr}$ or triphenylphosphine oxide, $\mathrm{Ph}_{3} \mathrm{PO}$ and nitric acid, $\mathrm{HNO}_{3}$ in the one hand, triphenyltin (IV) chloride, $\mathrm{SnPh}_{3} \mathrm{Cl}$ and, triphenylphosphine oxide, $\mathrm{Ph}_{3} \mathrm{PO}$ or urea, $\mathrm{CH}_{4} \mathrm{ON}_{2}$ in the other hand. These interactions afforded white powders whose infrared and Mössbauer characterization are carried out and reported herein characterization is reported herein.

\section{Materials and Methods}

\subsection{General}

Chemicals were purchased from Sigma-Aldrich (Germany) and were used without any further purification. Elemental analyses were performed at the Institut de Chimie Moléculaire, Université de Bourgogne Franche-Comté, Dijon, France. The infrared spectra were recorded on a Bruker Vector 22 spectrometer equipped with a Specac Golden Gate ${ }^{\mathrm{TM}}$ ATR device. The ${ }^{119}$ Sn Mössbauer spectra were obtained from the Centro de Desenvolvimento da Tecnologia Nuclear (CDTN), Servico de Nanotecnologia (SENAN), Laboratorio de Fisica Aplicada, Brazil. The ${ }^{119} \mathrm{Sn}$ Mössbauer spectra were obtained from a constant-acceleration spectrometer moving a $\mathrm{CaSnO}_{3}$ source at room temperature. The samples were analyzed at liquid $\mathrm{N}_{2}$ temperature, and the isomer shift values are given with respect to that source. All the Mössbauer spectra were computer-fitted assuming Lorentzian lineshapes. Mössbauer parameters are given in $\mathrm{mm} / \mathrm{s}$ [abbreviations: Q.
$\mathrm{S}=$ quadrupole splitting, I. $\mathrm{S}=$ isomer shift, $\Gamma=$ full width at half-height, $\mathrm{A}=\operatorname{area}(\%)$ ].

\subsection{Synthesis}

Cetyltrimethylbromide, $\mathrm{C}_{19} \mathrm{H}_{42} \mathrm{NBr}(\mathrm{m}=511 \mathrm{mg} ; 1.4 \mathrm{mmol})$, was preliminary dissolved in $15 \mathrm{~mL}$ of slightly hydrated methanol. A $10 \mathrm{~mL}$ methanol solution equimolar amount of dichloridotin (II) dihydrate, $\mathrm{SnCl}_{2} \cdot 2 \mathrm{H}_{2} \mathrm{O} \quad(\mathrm{m}=316 \mathrm{mg} ; 1.4$ mmol) was then added. A white powder was obtained after some days of a slow solvent evaporation at room temperature and was characterized as 1 . Compound 2 was isolated as a white powder by mixing $15 \mathrm{~mL}$ methanol solutions of dichloridotin (II) dihydrate, $\mathrm{SnCl}_{2} .2 \mathrm{H}_{2} \mathrm{O}(\mathrm{m}=519 \mathrm{mg} ; 2.3$ $\mathrm{mmol}$ ) and triphenylphosphine oxide, $\mathrm{Ph}_{3} \mathrm{PO}$ (m=641 mg; 2.3 mmol) and, an amount of nitric acid, $\mathrm{HNO}_{3}(4.6 \mathrm{mmol})$. Compound 3 was isolated as a white powder on allowing 15 $\mathrm{mL}$ acetonitrile solutions of triphenyltin (IV) chloride, $\mathrm{SnPh}_{3} \mathrm{Cl}(\mathrm{m}=386 \mathrm{mg} ; 1 \mathrm{mmol})$ and triphenylphosphine oxide, $\mathrm{Ph}_{3} \mathrm{PO}(\mathrm{m}=279 \mathrm{mg} ; 1 \mathrm{mmol})$ to react. Compounds 4 and 5 were obtained as white powders from reaction between $20 \mathrm{~mL}$ methanol solution of triphenyltin (IV) chloride, $\mathrm{SnPh}_{3} \mathrm{Cl}$ and $10 \mathrm{~mL}$ methanol solution of urea, $\mathrm{CH}_{4} \mathrm{ON}_{2}: \mathrm{SnPh}_{3} \mathrm{Cl}(\mathrm{m}=386$ $\mathrm{mg} ; 1 \mathrm{mmol})$ and $\mathrm{CH}_{4} \mathrm{ON}_{2}(\mathrm{~m}=121 \mathrm{mg} ; 2 \mathrm{mmol}), \mathrm{SnPh}_{3} \mathrm{Cl}$ $(\mathrm{m}=771 \mathrm{mg} ; 2 \mathrm{mmol})$ and $\mathrm{CH}_{4} \mathrm{ON}_{2}(\mathrm{~m}=61 \mathrm{mg} ; 1 \mathrm{mmol})$, respectively.

All mixtures were stirred around $2 \mathrm{~h}$ at room temperature under a not controlled atmosphere.

The analytical data [\% calculated ( $\%$ found $)]$, have allowed to suggest the following formulae (Table 1).

Table 1. Results of the elemental analyses of compounds 1-5.

\begin{tabular}{|c|c|c|c|c|c|c|c|}
\hline \multirow{3}{*}{ Compound } & \multirow{3}{*}{ Chemical formula } & \multicolumn{6}{|c|}{ Elemental analysis [\%] } \\
\hline & & \multicolumn{2}{|c|}{$\mathbf{C}$} & \multicolumn{2}{|l|}{$\mathbf{H}$} & \multicolumn{2}{|l|}{$\mathbf{N}$} \\
\hline & & Calc. & Found & Calc. & Found & Calc. & Found \\
\hline 1 & $\left(\mathrm{C}_{19} \mathrm{H}_{42} \mathrm{~N}\right)\left[\mathrm{SnCl}_{5}\right] .7 \mathrm{H}_{2} \mathrm{O}$ & 32.00 & 31.63 & 6.59 & 6.71 & 1.96 & 2.01 \\
\hline 2 & $4\left(\mathrm{SnCl}_{4} \mathrm{OPPh}_{3}\right) \cdot \mathrm{NO}_{3} \cdot \mathrm{H}_{3} \mathrm{O}$ & 38.93 & 39.86 & 2.88 & 3.45 & 0.67 & 0.63 \\
\hline 3 & {$\left[\mathrm{SnCl}_{4}\left(\mathrm{OPPh}_{3}\right)_{2}\right] \mathrm{C}_{6} \mathrm{H}_{6} \cdot 0.27 \mathrm{CH}_{3} \mathrm{CN}$} & 56.35 & 57.35 & 4.05 & 3.45 & 0.66 & 0.59 \\
\hline 4 & $\left.\left[\mathrm{SnCl}\left(\mathrm{NH}_{2}\right)_{3}(\mathrm{Ph})_{2} \mathrm{CO} . \mathrm{CH}_{3} \mathrm{OH}\right]\right] \mathrm{C}_{6} \mathrm{H}_{6}$ & 48.57 & 49.55 & 3.58 & 4.56 & 8.50 & 8.46 \\
\hline 5 & {$\left[\mathrm{SnCl}_{3}\left(\mathrm{NH}_{2}\right)(\mathrm{Ph})_{2} \mathrm{CO} . \mathrm{CH}_{3} \mathrm{OH}\right] \cdot 3 \mathrm{C}_{6} \mathrm{H}_{6}$} & 54.31 & 54.88 & 5.13 & 4.08 & 1.98 & 1.31 \\
\hline
\end{tabular}

Table 2. Coumpound and chemical formula.

\begin{tabular}{|c|c|}
\hline Compound & Chemical formula \\
\hline 1 & $\left(\mathrm{C}_{19} \mathrm{H}_{42} \mathrm{~N}\right)\left[\mathrm{SnCl}_{5}\right] .7 \mathrm{H}_{2} \mathrm{O}$ \\
\hline 2 & $4\left(\mathrm{SnCl}_{4} \mathrm{OPPh}_{3}\right) \cdot \mathrm{NO}_{3} \cdot \mathrm{H}_{3} \mathrm{O}$ \\
\hline 3 & {$\left[\mathrm{SnCl}_{4}\left(\mathrm{OPPh}_{3}\right)_{2}\right] \mathrm{C}_{6} \mathrm{H}_{6} \cdot 0.27 \mathrm{CH}_{3} \mathrm{CN}$} \\
\hline 4 & $\left.\left[\mathrm{SnCl}\left(\mathrm{NH}_{2}\right)_{3}(\mathrm{Ph})_{2} \mathrm{CO} . \mathrm{CH}_{3} \mathrm{OH}\right]\right] \mathrm{C}_{6} \mathrm{H}_{6}$ \\
\hline 5 & {$\left[\mathrm{SnCl}_{3}\left(\mathrm{NH}_{2}\right)(\mathrm{Ph})_{2} \mathrm{CO} \cdot \mathrm{CH}_{3} \mathrm{OH}\right] \cdot 3 \mathrm{C}_{6} \mathrm{H}_{6}$} \\
\hline
\end{tabular}

\section{Structure Description}

It seems worthy to outline the oxidation of tin (II) into tin (IV) in achievement processes of complexes 1 and 2, the $\mathrm{Sn}-\mathrm{Ph}$ bonds cleavage within the formation of compound 3, the $\mathrm{Sn}-\mathrm{Ph}$ bonds cleavage and urea deamination occurring during the formation processes of compounds 4 and 5 .

FT-IR spectroscopy
Compounds 1-5 were investigated by FT-IR spectroscopy in ATR mode. In the past, several works with FT-IR tetraalkylammonium cations, triphenyphosphine oxide, carboylates and multiples other vibration bands investigation have been reported [17]. The spectrum of 1 shows absorption bands that can be assigned to cetytrimethylammonium cation ( $\mathrm{N}-\mathrm{C}$, and $\mathrm{C}-\mathrm{H}$ bonds) and water molecules. In fact, vibration band located at $3400 \mathrm{~cm}^{-1}$ assigned to $\mathrm{O}-\mathrm{H}$ water stretching vibrations corroborate its presence in 1. Vibration bands located at $2922 \mathrm{~cm}^{-1}, 2849 \mathrm{~cm}^{-1}$ and $1468 \mathrm{~cm}^{-1}$ are attributed to $\mathrm{C}-\mathrm{H}$ stretching and bending vibrations, whereas those at $1200 \mathrm{~cm}^{-1}$ and $1100 \mathrm{~cm}^{-1}$ correspond to $\mathrm{C}-\mathrm{N}$ stretching and deformation vibrations of the cetytrimethylammonium. The rocking $\mathrm{CH}_{3}$ and $\mathrm{CH}_{2}$ vibrations are present about $1000-1100 \mathrm{~cm}^{-1}$ while their elongation vibrations are observed at $719 \mathrm{~cm}^{-1}$. The 
spectrum of 2 notices a band at $1150 \mathrm{~cm}^{-1}$ assigned to $\mathrm{PO}$ vibrations likewise a band at $1436 \mathrm{~cm}^{-1}$ which corresponds to nitrate stretching vibrations. The shift of the $v(\mathrm{PO})$ band is an important observation which can be explained by the coordination of $\mathrm{PPh}_{3} \mathrm{O}$ molecule to $\mathrm{Sn}$ atom through the oxygen atom. Additional vibration bands, characteristic of phenyl ligands, are also observed at $725 \mathrm{~cm}^{-1}$ and $695 \mathrm{~cm}^{-1}$ corresponding to phenyl groups $\mathrm{C}-\mathrm{H}$ and $\mathrm{C}=\mathrm{C}$ elongations, respectively. The spectrum of 3 evidences vibration bands at $1149 \mathrm{~cm}^{-1}, 722 \mathrm{~cm}^{-1}$ and $690 \mathrm{~cm}^{-1}$ attributed to $\mathrm{PO}$ vibrations and, $\mathrm{C}-\mathrm{H}$ and $\mathrm{C}=\mathrm{C}$ elongations of phenyl groups, respectively. The $v(\mathrm{PO})$ shift band is also observed enabled by the coordination of $\mathrm{PPh}_{3} \mathrm{O}$ molecule to tin atom. In the spectrum of 4 are ascertained $\mathrm{O}-\mathrm{H}$ vibrations at $3350 \mathrm{~cm}^{-1}$ and, $\mathrm{N}-\mathrm{H}$ stretching and bending vibrations at $2985 \mathrm{~cm}^{-1}$ and $2956 \mathrm{~cm}^{-1}$, and $1503 \mathrm{~cm}^{-1}$, respectively. Vibrations bands observed at $1628 \mathrm{~cm}^{-1}$ and $1262 \mathrm{~cm}^{-1}, 721$ and $692 \mathrm{~cm}^{-1}$ well corroborate the presence of carbonyl and phenyl groups, respectively. For 5 , the infrared spectrum enables to diagnose $\mathrm{N}-\mathrm{H}$ stretching and bending vibrations at $3014 \mathrm{~cm}^{-1}, 2978$ $\mathrm{cm}^{-1}$ and $1517 \mathrm{~cm}^{-1}, \mathrm{CO}$ antisymmetric and symmetric vibrations at $1597 \mathrm{~cm}^{-1}$ and $1248 \mathrm{~cm}^{-1}$, phenyl groups $\mathrm{C}-\mathrm{H}$ and $\mathrm{C}=\mathrm{C}$ elongations at $720 \mathrm{~cm}^{-1}$ and $688 \mathrm{~cm}^{-1}$ likewise.

Infrared characteristic absorption vibration bands evidence presence of moieties that are present in the proposed formulae. Thus, the infrared investigations are in accordance with suggested formulae.

Mössbauer spectroscopy and molecular structures

Compounds 1-5 were also investigated by tin mössbauer spectroscopy (Table 2).

Table 3. Results of the mössbauer analyses of compounds 1-5.

\begin{tabular}{llllll}
\hline Compound & Phases & $\begin{array}{l}\text { IS }(\mathbf{m m} / \mathbf{s}) \\
(\mathbf{0 , 0 5})\end{array}$ & $\begin{array}{l}\mathbf{Q S}(\mathbf{m m} / \mathbf{s}) \\
\mathbf{( \pm 0 , 0 5})\end{array}$ & $\begin{array}{l}\Gamma(\mathbf{m m} / \mathbf{s}) \\
(\mathbf{\pm 0 , 0 4})\end{array}$ & $\begin{array}{l}\text { Area }(\mathbf{\%}) \\
( \pm \mathbf{1})\end{array}$ \\
\hline 1 & 1 & 0.17 & 0.56 & 0.99 & 100 \\
2 & 1 & 0.11 & 0.53 & 0.96 & 100 \\
3 & 1 & 0.20 & 0.49 & 0.90 & 100 \\
4 & 1 & 0.12 & 0.60 & 0.97 & 100 \\
5 & 1 & 0.21 & 0.56 & 0.91 & 100 \\
\hline
\end{tabular}

For 1, the mössbauer parameters evidence one arrangement fashion at tin atom. The isomer shift and the quadrupole splitting values found for $\left[\mathrm{SnCl}_{5}\right]^{-}$are $0.59 \mathrm{~mm}$. $\mathrm{s}^{-1}$ and $0.77 \mathrm{~mm} . \mathrm{s}^{-1}$, respectively [18]. The isomer shift and the quadrupole splitting values of $0.17 \mathrm{~mm} . \mathrm{s}^{-1}$ and $0.56 \mathrm{~mm}$. $\mathrm{s}^{-1}$ are in accordance with an hexacoordinated metallic chloride component and thus corroborate the suggested formula [18]. Various $\left[\mathrm{SnCl}_{6}\right]^{2-}$ containing crystalline structures are known, to date $[19,20]$. We suggest in the solid state, on the basis of spectroscopic data, a discrete structure with a $\mathrm{SnCl}_{5}{ }^{-}$complex-anion coordinated to a water molecule to give the $\left[\mathrm{SnCl}_{5}\left(\mathrm{H}_{2} \mathrm{O}\right)\right]^{-}$complex which electrostatically interacts with the cetyltrimethylammonium cation (Figure 1); the remaining water molecules are considered as lattice.

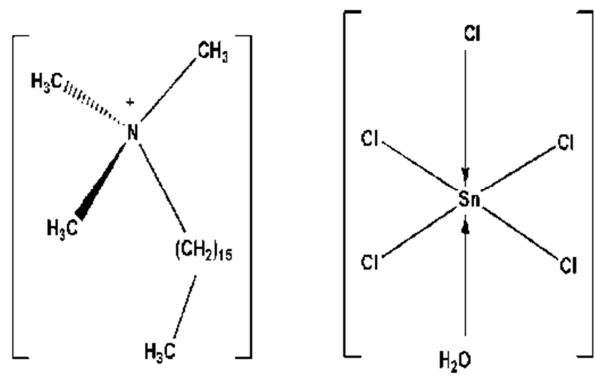

$6 \mathrm{H}_{2} \mathrm{O}$

Figure 1. Proposed structure for 1.

For 2, the mössbauer parameters confirm the presence of only coordinated trans-coordinated $\mathrm{SnCl}_{4}$ molecules [21-24]. The Dakar group has yet reported complexes $\left[\mathrm{NO}_{3}\left(\mathrm{SnPh}_{3} \mathrm{NO}_{3}\right)\left(\mathrm{SnPh}_{3} \mathrm{Cl}\right)_{2}\right]\left[\mathrm{Et}_{4} \mathrm{~N}\right]^{+}$and $\left[\left(\mathrm{PhCH}_{2}\right) \quad \mathrm{Ph}_{3} \mathrm{P}\right.$ $\left.\left(\mathrm{NO}_{3}\right)\right]\left[\left(\mathrm{SnPh}_{3} \mathrm{Cl}\right)_{3}\right]$ whose described structures are comprised of a central tricoordinating nitrate anion linked to tin centres $[14,25]$. In comparison to this nitrate behaviour, we therefore suggest, in the solid state, a two components structure. The first component contains a central tridentate nitrate anion coordinated to tin centres of $\mathrm{SnCl}_{4}$ molecules which are, each one, yet coordinated by a $\mathrm{PPh}_{3} \mathrm{O}$ molecule. The second component is a $\mathrm{SnCl}_{4}$ molecule coordinated to an oxonium $\left(\mathrm{H}_{3} \mathrm{O}^{+}\right)$cation and to a $\mathrm{PPh}_{3} \mathrm{O}$ molecule. In both components, the tin atom is about a centre of an octahedron (Figure 2).

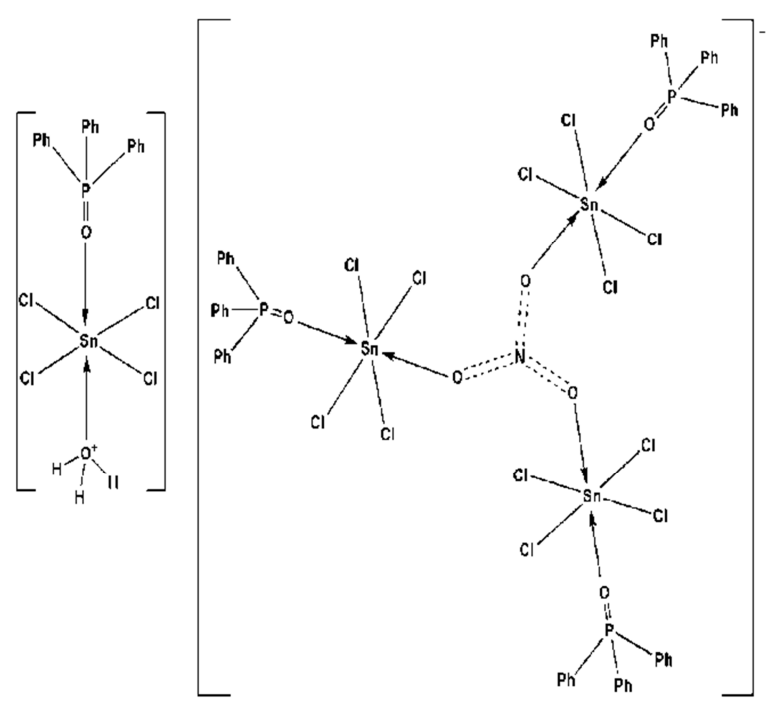

Figure 2. Proposed structure for 2.

For 3, the mössbauer parameters are consistent with cis-coordinated $\mathrm{SnCl}_{4}$ molecule containing compounds then with the proposed formula. In the past, numerous structures with various $\mathrm{O}$-donor ligands coordinated to $\mathrm{SnCl}_{4}$ molecules in a cis or trans fashion were described, especially the crystal and mössbauer relationship of $\mathrm{SnI}_{4} \mathrm{~L}_{2}$ (L=bipy, $\mathrm{Ph}_{3} \mathrm{PO}$ or $\mathrm{Ph}_{2} \mathrm{SO}$ ) complexes which exhibit cis-structures [26]. The cis-trans isomers of the adducts $\mathrm{SnCl}_{4} \mathrm{~L}_{2} \quad(\mathrm{~L}=\mathrm{N}$, $\mathrm{N}$-dimethylformamide (dmf), N, N-dimethylacetamide (dma), or dimethyl sulphoxide (dmso)) have also been reported [21]. On the basis of the spectroscopic data we suggest, in the solid state, in comparison to the known $\mathrm{SnI}_{4} \mathrm{~L}_{2}$ and cis- $\mathrm{SnCl}_{4} \mathrm{~L}_{2}$, an 
iso-structural discrete structure comprised of a $\mathrm{SnCl}_{4}$ molecule cis-coordinated in an octahedral fashion to two $\mathrm{PPh}_{3} \mathrm{O}$ molecules, the benzene molecule is considered lattice (Figure 3).
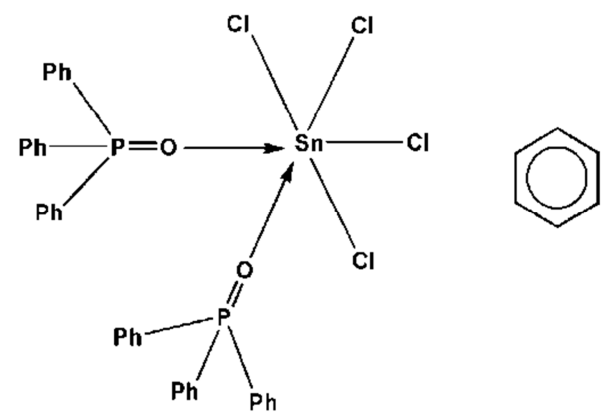

Figure 3. Proposed structure for 3.

For 4 and 5, the mössbauer quadrupole splitting low values of $0.60 \mathrm{~mm} . \mathrm{s}^{-1}$ and $0.56 \mathrm{~mm} . \mathrm{s}^{-1}\left(<1 \mathrm{~mm} . \mathrm{s}^{-1}\right)$ evidence clearly absence of $\mathrm{SnPh}_{3}$ residues, thus $\mathrm{Sn}-\mathrm{Ph}$ bonds cleavage. In fact, the $\mathrm{Sn}-\mathrm{Ph}$ containing compounds isomer shift and the quadrupole splitting values are generally higher than $1 \mathrm{~mm} . \mathrm{s}^{-1}$ $[14,18,21,27]$. These mössbauer parameters are in accordance with the proposed formulae presumably obtained after an in situ urea degradation and $\mathrm{Sn}-\mathrm{Ph}$ bonds cleavage followed by a rearrangement. The presumable exchange is uncommon. In the past, several compounds occurring a $\mathrm{Sn}-\mathrm{Ph}$ bond cleavage during their isolation processes have been reported $[15,16]$. On the basis of spectroscopic data we suggest, in the solid state, a discrete structure which is comprised of a central tin atom coordinated to:

i. For 4, a chlorine atom and three amino groups giving a $\mathrm{SnCl}\left(\mathrm{NH}_{2}\right)_{3}$ molecule whose octahedral coordination sphere is completed by $\mathrm{Ph}_{2} \mathrm{CO}$ and methanol molecules through $\mathrm{Sn}-\mathrm{O}$ bonds, the benzene molecules being lattice (Figure 4).

ii. For 5 , three chlorine atoms and one amino group giving a $\mathrm{SnCl}_{3}\left(\mathrm{NH}_{2}\right)$ molecule whose octahedral coordination sphere is completed by $\mathrm{Ph}_{2} \mathrm{CO}$ and methanol molecules through $\mathrm{Sn}-\mathrm{O}$ bonds, the benzene molecules being lattice (Figure 5).
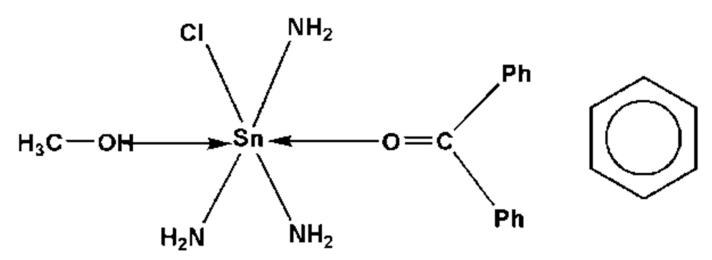

Figure 4. Proposed structure for 4.

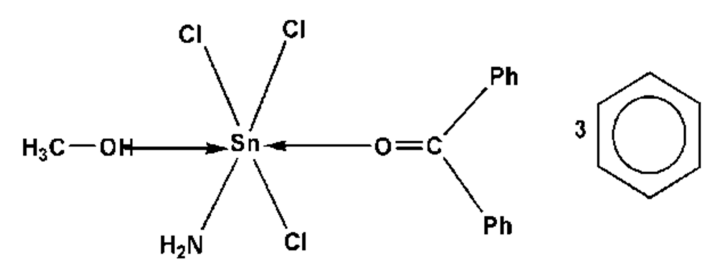

Figure 5. Proposed structure for 5.
In the proposed structures except of 2, O- $\mathrm{H}$ group of methanol molecule, $\mathrm{N}-\mathrm{H}$ amino group or $\mathrm{O}-\mathrm{H}$ water molecules may interact through hydrogen bonds leading to supramolecular architectures.

\section{Conclusion}

In this study, the reaction between dichloridotin (II) dihydrate, $\mathrm{SnCl}_{2} \cdot 2 \mathrm{H}_{2} \mathrm{O}$ exhibits a tin oxidation from $2+$ to $4+$. This oxidation led to the isolation of three complexes which have discrete structures. Interactions between urea and triphenyltin chloride, $\mathrm{SnPh}_{3} \mathrm{Cl}$ diagnosed an event in tin chemistry, an uncommon process exchange between species giving rise to aminochlorotin (IV) based compounds, when reactions are carried out in polar organic solvents, methanol for example, and in a not controlled atmosphere. This exchange follows a 1: 3 (default material: excess material) ratio and can be explained by deamination of urea and dearylation, $\mathrm{Sn}-\mathrm{Ph}$ bonds cleavage of $\mathrm{SnPh}_{3} \mathrm{Cl}$. Further studies in attempts to well understand the yet unknown transformation processes leading to the isolation of the aminochlorotin (IV) compounds and, isolate their single crystals are in progress in our Laboratory (LA.CHI.MI.A).

\section{Acknowledgements}

The authors acknowledge the Cheikh Anta Diop University of Dakar (Sénégal), the University of Bourgogne Franche-Comté, Dijon (France) and the Centro de Desenvolvimento da Tecnologia Nuclear (CDTN), Servico de Nanotecnologia (SENAN), Laboratorio de Fisica Aplicada, Pampulha, Belo Horizonte (Brazil) for facilities.

\section{References}

[1] Carraher C. E., Roner M. R., Frank J., Slawek P., Mosca F., Shahi K., Moric-Johnson A. and Miller L. (2019). Organotin Polymers for the Control of Pancreatic Cancer, OBM Hepatology and Gastroenterology. 3 (2): doi: 10.21926/obm.hg.1902019.

[2] Roner M., Shahi K., Battin A., Barot G. and Arnold T. (2014). Organotin Polymers As Chemotherapeutic Agents: Breast and Pancreatic Cancers, Journal of Polymer Materials. 31 (1): 1-14.

[3] Barot G., Roner M. R., Naoshima Y., Nagao K., Shahi K. and Carraher C. E. (2009). Synthesis, structural characterization, and preliminary biological characterization of organotin polyethers derived from hydroquinone and substituted hydroquinones, Journal of Inorganic and Organometallic Polymers and Materials. 19 (1): 12-27.

[4] Roner M. R., Shahi K. R., Barot G., Battin, A. and Carraher C. E. (2009). Preliminary results for the inhibition of pancreatic cancer cells by organotin polymers, Journal of Inorganic and Organometallic Polymers and Materials.. 19 (3): 410-414.

[5] Carraher C., Roner M., Lynch M., Moric-Johnson A., Miller L., Slawek P., Mosca F. and Frank J. (2018). Organotin poly (ester ethers) from salicylic acid and their ability to inhibit human cancer cell lines, Journal of Clinical Research in Oncology. 1 (1): 1-11. 
[6] Carraher Jr C. and Roner M. (2014). Organotin polymers as anticancer and antiviral agents, Journal of Organometallic Chemistry. 751: 67-82.

[7] Sirajuddin M., Ali S., McKee V., Zaib S. and Iqbal J. (2014). Organotin (IV) carboxylate derivatives as a new addition to anticancer and antileishmanial agents: design, physicochemical characterization and interaction with Salmon sperm DNA, RSC Advances. 4: 57505-57521.

[8] Meneghetti M. R. and Meneghetti S. M. P. (2015). Sn (IV)-based organometallics as catalysts for the production of fatty acid alkyl esters, Catalysis Science \& Technology. 5: 765771.

[9] Mao W., Bao K., Feng Y., Wang Q., Li J. and Fan Z. (2015). Synthesis, crystal structure, and fungicidal activity of trioriganotin (IV) 1-methyl-1H-imidazole-4-carboxylates, Main Group Metal Chemistry. 38: 27-30.

[10] Kagan C. R., Breen T. L. and Kosbar L. L. (2001). Patterning organic-inorganic thin-film transistors using microcontact printed templates, Applied Physics Letters. 79 (21): 35363538 .

[11] Nardelli M., Pelizzi C. and Pelizzi G. (1976). Structulal researches on organotin (IV) compounds. Synthesis and structure of nitratotriphenyl (triphenylphosphine oxide) tin (IV), Journal of Organometallic Chemistry. 112: 263-272.

[12] Nardelli M., Pelizzi C. and Pelizzi, G. (1977). Structulal researches on nitrato complexes of organotin: Coordinative interactions $\mathrm{Sn}-\mathrm{O}$ in nitratotriphenyl (triphenylarsine oxide) tin (IV), Journal of Organometallic Chemistry. 125: 161-172.

[13] Pelizzi C., Pelizzi G. and Tarasconi, P. A. (1977). Structulal researches on nitrato complexes of organotin: Coordinative interactions $\mathrm{Sn}-\mathrm{O}$ in nitratotriphenyl (pyridine $\mathrm{N}$-oxide) tin (IV), Journal of Organometallic Chemistry. 124: 151-160.

[14] Renamy S. V., Okio K. Y. A., Diop M. B. and Diop L. (2019). Some organotin (IV) nitrate adducts: syntheses, far infrared and mössbauer characterization, International Journal of Advanced Research. 7 (5): 12-22.

[15] Chandrasekhar V., Gopal K., Sasikumar P. and Thirumoorthi, R. (2005). Organooxotin assemblies from Sn-C bond cleavage reactions, Coordination Chemistry Reviews. 249: 1745-1765.

[16] Gueye N., Diop L., Molloy K. C. and Kociok-Kohn G. (2010). Bis (dicyclohexylammonium) $\mu$-oxalato- $\kappa^{4} O^{1}, O^{2}: O^{1}, O^{2}$-bis [aqua (oxalato- $\kappa^{2} O^{1}, O^{2}$ ) diphenylstannate (IV)], Acta Crystallographica. E66: m1645-m1646.
[17] Nakamoto K. (1997). Infrared and Raman Spectra of Inorganic and Coordination Compounds, Edited by John Wiley and Sons, 5th Edition.

[18] Parish R. V. and Platt R. H. (1969). Studies in Mossbauer Spectroscopy. Part I. Interpretation of Quadrupole Splitting Data for Tin (IV) Compounds, Journal of the Chemical Society A: $2145-2150$.

[19] Reiss G. J. and Helmbrecht C. (2012). Bis (diisopropylammonium) hexachloridostannate (IV), Acta Crystallographica. E68: m1402-m1403.

[20] vanMegen M., Prömper S. and Reiss G. J. (2013). Bis (3-azaniumylpyridin-1-ium) hexachloridostannate (IV) dichloride, Acta Crystallographica. E69: m217.

[21] Tudela D. and Fernandez, V. (1985). Mossbauer Study of the cis-trans Isomers of Tin (IV) Complexes. Some Considerations about the Sign of the Electric-field Gradient, Journal of the Chemical Society Dalton Transactions. 1281-1284.

[22] Tudela D., Muro C., Fernandez V. and Tornero J. D. (1986). Vibrational and ${ }^{119} \mathrm{Sn}$ Mössbauer Study of Tin Tetrahalide Complexes with Benzofuroxan Derivatives, Zeitschrift für anorganische und allgemeine Chemie. 538: 201-206.

[23] Tudela D., Khan M. A. and Juckermant J. J. (1991). Structural Information from the Mossbauer Quadrupole Spfitting of Tin (IV) Chloride Complexes, Structural Chemistry. 2: (31) 239-(35) 243.

[24] Tudela D. and Tornero, J. D. (1993). cis-trans Isomerism in tetrabromobis (1, 3-dimethylurea) tin (IV), Inorganica Chimica Acta. 214: 197-199.

[25] Diop T., Diop L., Michaud F. and Ardisson J. D. (2013). Synthesis and crystal structure of $\mathrm{Et}_{4} \mathrm{NNO}_{3}\left(\mathrm{SnPh}_{3} \mathrm{NO}_{3}\right)\left(\mathrm{SnPh}_{3} \mathrm{Cl}\right)_{2}$, Main Group Metal Chemistry. 36: 83-88.

[26] Tudela D., Sanchez-Herencia A. J., Diaz M., Fernandez-Ruiz R., Menéndez N. and Tornero J. D. (1999). Mössbauer spectra of tin (IV) iodide complexes, Journal of the Chemical Society Dalton Transactions. 4019-4023.

[27] Diallo W., Toure A., Diop C. A. K. and Sidibe M. (2018). Some new oxalato and sulfato $\mathrm{SnR}_{3}(\mathrm{R}=\mathrm{Me}, \mathrm{Ph})$ and $\mathrm{SnR}_{2}{ }_{2} \mathrm{Cl}\left(\mathrm{R}^{\prime}=\mathrm{Ph}\right.$, $\mathrm{Bu})$ residues containing derivatives and complexes: synthesis, infrared, NMR and Mössbauer studies, International Journal of Advanced Research. 6 (2): 861-870. 